\title{
Deleterious DICER1 Gene Mutation
}

National Cancer Institute

\section{Source}

National Cancer Institute. Deleterious DICER1 Gene Mutation. NCI Thesaurus. Code C162745.

A change in the nucleotide sequence of the DICER1 gene that is associated with increased risk of disease. 